\title{
Dynamic Behavior of Steel Fiber Reinforced Concrete Beam Under loading
}

\author{
Syed Sabihuddin \\ Department of Civil Engineering Prof Ram Mega College of Engineering Badnera Amravati
}

\begin{abstract}
This manuscript describe the power of steel fiber sharing on the final strength of concrete beams. An investigational \& analytical study of the performance of concrete beam resistant by means of Conservative strengthen bar and steel fibers beneath lateral load be available. It is now well recognized that one of the important properties of steel fiber reinforced concrete is its superior resistance to cracking and Crack spread. As a result of this ability to capture cracks, fiber composites possess increased extensibility and tensile strength, both at first crack and at ultimate load and the fibers are able to hold the matrix together even after extensive cracking. The net result of all these is to pass on to the fiber composite pronounced post-cracking ductility which is unheard of in ordinary concrete. The transformation from a brittle to a yielding type of material would increase substantially the energy absorption characteristics of the fiber composite and its ability to withstand repeatedly applied, upset or impact loading. Tests on conventionally reinforced concrete beam specimens, containing steel fibers in different size, have been conducted to establish load-deflection curves. It was observed that (SFRC) beams showed enhanced properties compared to that of RC beams with steel fibers. The experimental investigations are validated with the analytical studies carried out by finite element models using.

Keywords: Steel fiber, concrete, break, ductility, tools
\end{abstract}

\section{Introduction}

SFRC is a complex material made of cement, water, fine and coarse collective, and a dispersal of discontinuous, small fibers. These short separate fibers are uniformly distributed and arbitrarily oriented. They are varied with concrete before pouring. The unbreakable concrete structures are subjected to lateral loads during dynamic loads such as underground eruption shocks, traffic loads on the bridges, etc. It is well known that simple concrete is brittle and weak below flexural loads. To eliminate the disadvantages of plain concrete is added fibers into concrete mix. All admixtures meeting ASTM specifications for use in concrete are suitable for use in SFRC.Steel fiber-reinforced concrete (SFRC) has gain greater than before popularity in construction industries in recent years.

\section{Property of Concrete material Improved by Steel Fibers:}

Flexural power: Flexural winding force can be increased of up to 3 times more compare to conventional concrete.

Impact Resistance: an impact is a high force or shock applied over a short time period when two or more bodies collide

Permeability: The material is fewer absorbent.

Abrasion Resistance: extra effectual composition against scrape and spell.

Shrinkage: decrease crack can be eliminating.

Corrosion: Corrosion may affect the material other than it will be limited in sure area.

\section{The aim of this study is to:}

\section{Aim of work}

Study the mechanical properties like flexural force, modulus of softness flexure beam and Cylinders. Study ductility requirement, instant rotary motion ability, and energy absorption capacity for SFRC beams under loading using hybrid steel fibers of dissimilar quantity fraction get better the resistance of conventionally reinforced structural members to cracking, deflection and other Service ability conditions; by utilize the intrinsic substance properties of fiber concrete.

\section{Range:}

The range of work is to study the behavior of steel fiber reinforced beams under lateral loading and Comparing the consequences both analytically using a general purpose limited element-modeling wrap upand experimentally. The parameters investigated are: 


\section{Investigate impact:}

It is obviously see as of the text that the behavior of beam is affect through the properties of core concrete. Ductility be attractive in unbreakable concrete frames under seismic loading. Ductility is usually achieved by provided that closely spaced flat tie, other than this causes difficulty inside insertion concrete in densely reinforced portions resulting in bad concreting. To keep away from such closely spaced stirrups, imprisonment characteristics of core concrete has to be better, which increase the ductility of the core concrete. In this respect, steel fiber reinforced concrete (SFRC) which posses ductility, hardiness and tensile power additional than the plain straight concrete can be careful in the way of put back the plain concrete .It be predictable so as to use of SFRC can get rid of partly or completely the tie ,therefore avoid the overcrowding of strengthening.

\begin{tabular}{|c|c|c|c|}
\hline Water & cement & $\begin{array}{c}\text { Fine } \\
\text { aggregate }\end{array}$ & $\begin{array}{c}\text { Coarse } \\
\text { aggregate }\end{array}$ \\
\hline 80 & 3 & 7 & 10 \\
\hline 40 & 3 & 7 & 10 \\
\hline
\end{tabular}

Materials:

\section{Materials and Methods}

The materials used in the experimental work are tested for their properties and the details are furnished. Raw materials were used for preparation of the specimen Ordinary Portland Cement Coarse aggregate with $10 \mathrm{~mm}$ maximum size Fine collective Steel Reinforcement High Yield for main bar $12 \mathrm{~mm}, 10 \mathrm{~mm}$ and kind steel for cut off reinforcement $8 \mathrm{~mm}$, plywood with width $12 \mathrm{~mm}$ to set formwork

\section{Information of Fibers:}

Fiber used - straight end, Deformed with following aspect ratios and diameters. The roperties of fibers are given

\section{Combine Design:}

Considering the capacity of beam testing machine, the grade of the concrete is M15. The mix design of the M25 grade concrete as per IS: 456:2005.

\section{Aim of RC Beam:}

The RC Beam is calculated based on the load carrying ability of the testing apparatus. The limiting load applied on the beam from the apparatus is considered as $250 \mathrm{kN}$. The dimensions and reinforcement details for the beam are given below. The detailing of the beam is done as normal detailing and ductile detailing.

L - $1700 \mathrm{~mm} \mathrm{~B} \mathrm{-} 140 \mathrm{~mm} \mathrm{D} \mathrm{-} 220 \mathrm{~mm}$

\section{Experimental method:}

Every one beams after cast is cured for 25 days prior to testing. Lateral Loading is the application of incremental Push and Pull Load. The study is also known as Push-Pull analysis. The loads are applied incrementally as positive and negative loads. Hydraulic jack and load cells 20 tones or 25 tones are placed above and below the beam in order to get the effect of lateral loading. Every one beam is tested for corresponding load increment and finally the behavior of beam is studied

\section{Analytical examination:}

The study on the structural outline is basically a deflection controlled analysis therefore the analysis is approved out by the application of sideways force. The mains model is analyses and the dislocation results areobserved from lateral loading by applying each load increment both in positive direction and in negative direction. Figure showing the reinforcement details in Dynamic Behavior Reinforcement shown below.

\begin{tabular}{|c|c|c|c|}
\hline s.no & Fibre & $\begin{array}{c}\text { Aspect } \\
\text { ratio } \\
(1 / \mathrm{d})\end{array}$ & $\begin{array}{c}\text { Length } \\
(\mathrm{mm})\end{array}$ \\
\hline 1 & $\begin{array}{c}\text { straight } \\
\text { End -1 }\end{array}$ & 90 & 65 \\
\hline 2 & $\begin{array}{c}\text { Straight } \\
\text { End -2 }\end{array}$ & 58 & 30 \\
\hline 3 & $\begin{array}{c}\text { straight } \\
\text { End -3 }\end{array}$ & 47 & 40 \\
\hline 4 & Deformed & 50 & 40 \\
\hline
\end{tabular}



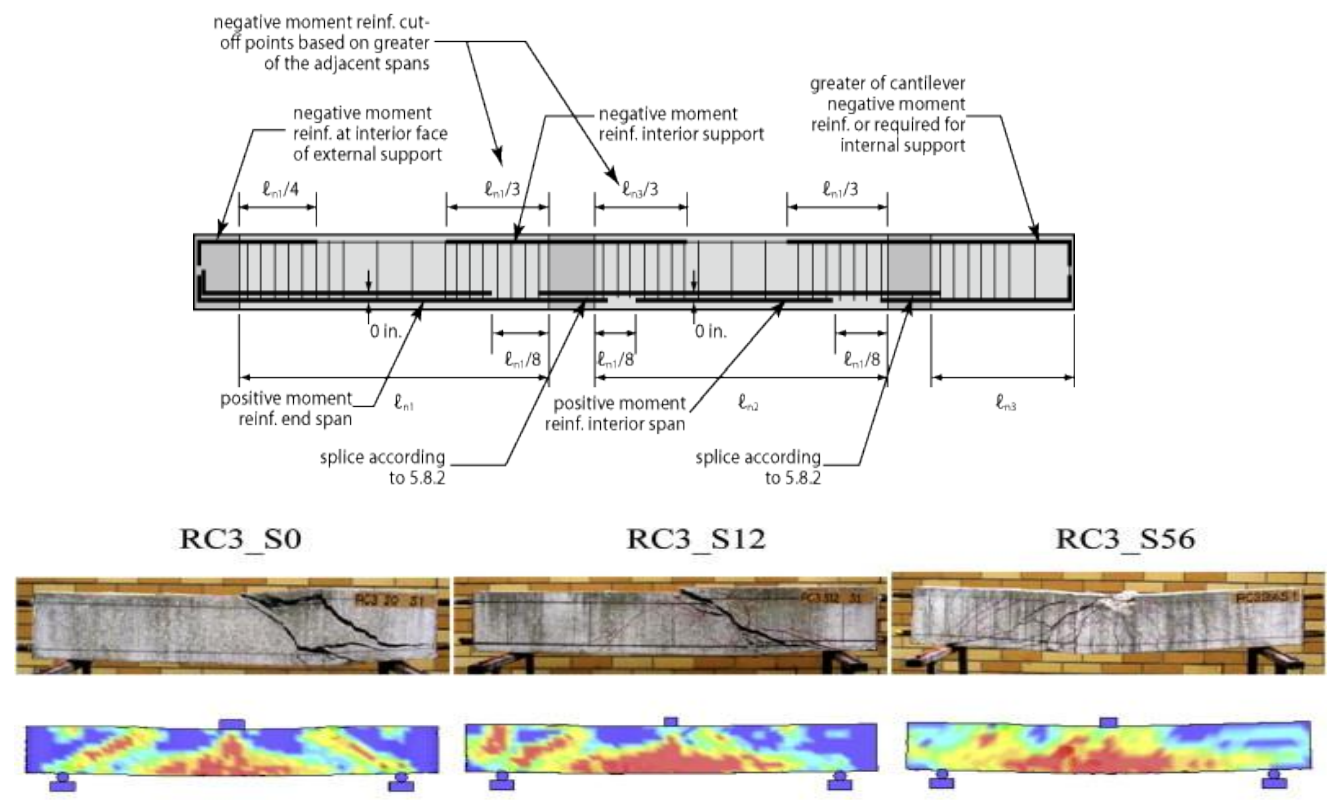

Static

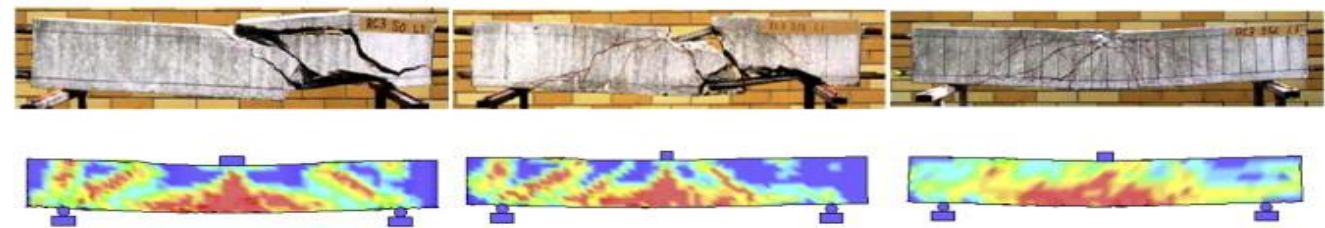

Low
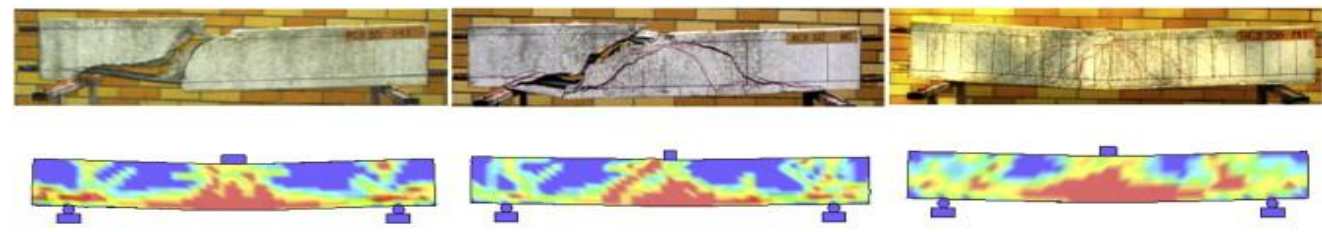

Medium

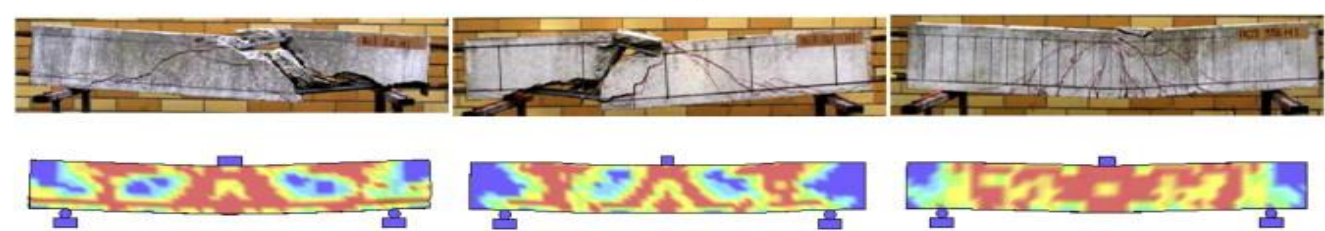

High

\section{Conclusion}

The investigational values of the strain and deflection of steel fiber reinforced concrete beams are comparing with that of the matching estimated values of the strain and deflection of reinforced concrete beams without fiber. The contrast reveals that the strength depends on the presence of fiber and it increases with decrease in the spacing of stirrups increase in the percentage of web reinforcement. The ultimate strength of SFRC beams is methodically obtained. The analytical results were compared with the investigational results

\section{Acknowledgement}

I would like to thankto the Principal, Prof Ram Mega College of Engineering \& Management Badnera Amravati, for providing necessary facilities. 


\section{References}

[1]. S. Pant Avinash1, R. Suresh Parekar"Steel fiber reinforced concrete beams under combined torsion -bending- shear" Journal of Civil Engineering (IEB) 38(1) 31-38

[2]. R.P. Dhakal and H.R. Song (2009) "Effect of bond on the behavior of steel fiber reinforced concrete beams" ICI Journal, Vol.1, and No.4

[3]. MukeshShukla(2011)“Behavior of Reinforced Concrete Beams with Steel Fibers under Flexural Loading” International Journal of Earth Sciences and Engineering ISSN 0974-5904, Volume 04, No 06 SPL, October, pp 843-846

[4]. Florian Finck(2010) "Acoustic Emission analysis of SFRC Beams under cyclic bending loads" Journal of Civil Engineering (IEB) 38(1) 21-28

[5]. Vengatachalapathy.V 1 ,Ilangovan.R(2010 )“A Study on Steel Fiber Reinforced Concrete Deep Beams With and without Openings "International journal of civil and structural engineering, Volume 1, No. 3

[6]. Pant Avinash S, Parekar Suresh R (2009) "Steel Fiber Reinforced Concrete Beams under Bending, Shear And Torsion Without Web Reinforcement" International Journal of Recent Trends in Engineering, Vol. 1, No. 6

[7]. I.J Sluys And R.DeBorst(2010)“Computational modeling of impact test on steel fiber reinforced concrete beams" Journal of civil Engineering, Vol. 2, No.4

[8]. Hai H. Dinh and James K. Wight (2009) "Shear behavior of steel fiber -reinforced concrete beams without stirrup reinforcement"'ISET Journal of Earthquake Technology, Technical Note, Vol. 44, No. 3-4

[9]. Hamid Pesaran Behbahani1, BehzadNematollahi(2011) "Flexural behavior of steel-fiber-added-RC (sfrc) Beams with C30 and C50 classes of concrete” Engineering structures ,Science Direct 37 